\title{
Toxic Effect of Imidacloprid on Protein Content in Estuarine Clam, Katelysia opima (Gmelin)
}

\author{
Madhura D. Mukadam, Arvind S. Kulkarni \\ Department of Zoology, R. P. Gogate College of Arts \& Science and R. V. Jogalekar College of Commerce, \\ Ratnagiri, India \\ Email: madhuramukadam111@gmail.com
}

Received 27 August 2014; revised 7 October 2014; accepted 10 November 2014

Copyright (C) 2014 by authors and OALib.

This work is licensed under the Creative Commons Attribution International License (CC BY). http://creativecommons.org/licenses/by/4.0/

\section{(c) (i) Open Access}

\begin{abstract}
The indiscriminate use of insecticide has caused serious pollution problems of aquatic ecosystems. Imidacloprid is mainly used to control sucking insects such as rice hoppers, aphids, thrips and some species of beetles. Further it is known to cause apathy, myatonia, tremor and myospasms in humans. Toxic effects of imidacloprid were estimated by selecting Katelysia opima as an animal model. Effect of imidacloprid on total protein content of gill, mantle, hepatopancreas, foot, male gonad and female gonad of estuarine clam, Katelysia opima was studied. The clams were exposed to $86.6 \mathrm{ppm}$ of imidacloprid or acute treatment; it was found that there was decrease in protein content in various tissues in $\mathbf{L C}_{50}$ as compared to control. In $\mathbf{L C}_{50}$ group protein content was decreased in mantle hepatopancreas, foot male and female gonad as compared to the control. This decrease was more in foot, male gonad and female gonad in $\mathrm{LC}_{50}$ group as compared to $\mathrm{LC}_{0}$ group. Gill, mantle and hepatopancreas showed increase in protein content in $\mathrm{LC}_{50}$ group as compared to $\mathrm{LC}_{0}$ group. Decrease in protein content was more in foot, male gonad and female gonad in $\mathrm{LC}_{50}$ group due to the higher concentrations of imidacloprid.
\end{abstract}

\section{Keywords}

Imidacloprid, Protein Content, Katelysia opima

Subject Areas: Toxicology, Zoology

\section{Introduction}

Imidacloprid $\left(\mathrm{C}_{9} \mathrm{H}_{10} \mathrm{ClN}_{5} \mathrm{O}_{2}\right)$ is an insecticide that was made to mimic nicotine. It is used to control sucking insects, termites, some soil insects and fleas on pets. Imidacloprid is much more toxic to insects and other inverte- 
brates. It acts on the nervous system of insect which causes a blockage in the neural pathway. This blockage leads to the accumulation of acetyl choline, an important neurotransmitter, resulting in the insect's paralysis and eventually death. It is effective on contact and via stomach action [1]. Imidacloprid is found in the variety of commercial insecticides [2]. In market, the products like Admire, Confidor, Premier, Provado, etc. are available with imidacloprid as an active ingredient. In Ratnagiri, it is mainly used against mango hoppers, mango mealy bugs, aphids and other insect pests of mango. A maximum portion of pesticides gets concentrated in the soil nearby. Heavy rain freshets bring imidacloprid impregnated soil into Bhatye estuary, Ratnagiri (Maharashtra). This estuary acts as a cradle bed for estuarine flora and fauna, including economically important fauna such as fish, oysters and clams.

It is bioaccumulated in estuarine fauna like estuarine clams. Clams are abundant along the coast of Ratnagiri (Maharashtra) and are important with reference to the food value. Shells are mainly used as a raw material for lime factories along the coast. In spite of the fact, much less attention has been paid by researchers with regard to effect of pollution on estuarine clams. Clams are known to accumulate pesticides without getting killed easily and have relatively long life span. Toxic material can induce considerable change in protein content of bivalves. The depletion was observed in total protein content level in all tissues of fresh water bivalves, Parreysia cylindrica after cypermethrin exposure [3]. Significant alterations in protein content were observed in M. meretrix and K. opima after exposure to fluoride [4]. Similarly there was depletion of total protein in estuarine clam, Meretrix meretrix after exposure to cypermethrin [5].

Since biochemical assessment is a useful tool to measure environmental quality, the present work is aimed to study the effect of imidacloprid on protein metabolism in estuarine clam, Katelysia opima (Gmelin).

\section{Materials and Methods}

The experimental clams (Katelysia opima) used for the present study were collected from Bhatye estuarine region, Ratnagiri coast, Maharashtra state. Clams of medium size $(4.0-4.4 \mathrm{cms})$ were selected and brought to the laboratory and stocked in the plastic containers containing filtered, aerated estuarine water for $48 \mathrm{hr}$. Well acclimatized clams to the laboratory condition were grouped in ten and kept into plastic containers containing five liters filtered estuarine water. Static bioassay tests were conducted for $96 \mathrm{hr}$ by using imidacloprid (17.8\% SL). For every experiment, a control group of clams was also run simultaneously. For the selection of test concentrations, some pilot tests were performed to determine the range of toxicity of the pesticide. The range of concentrations selected was such that it resulted in zero to hundred percent mortality for short term exposures. The formula used to prepare the pesticide solution is as follows:

$$
\text { No. of } \mathrm{ml} \text { for required volume }=\frac{\text { required } \mathrm{ppm} \times \text { required volume }}{\text { Stock solution }}
$$

The volume of the container was maintained at $5 \mathrm{~L}$ for each. Observations were made at $12,24,36,48,60,72$, 84 and 96 hours.

The $\mathrm{LC}_{50}$ value for each time period was estimated by a regression analysis determined for the log of concentrations and percentage survival of the clam. The percentage mortality in various concentrations at particular period were converted into probit values and plotted against the log of concentrations. The toxicity tests were repeated three times and $\mathrm{LC}_{0}$ and $\mathrm{LC}_{50}$ values were determined.

After acute exposure to imidacloprid the various tissues (gill, mantle, hepatopancreas, foot, male and female gonad) of live clams were pooled, weighed and dried in an oven at $70^{\circ} \mathrm{C}$ until a constant weight was obtained. Oven dried tissues were used for biochemical analysis. Live clams were analyzed for total proteins [6].

\section{Results}

Imidacloprid induced alterations in the total protein content in different organs of the estuarine clam, Katelysia opima are shown in Table 1.

In control group of Katelysia opima showed protein content in ascending order of, hepatopancreas < gills < mantle $<$ foot $<$ female gonad $<$ male gonad, containing $13.732 \pm 0.434524,16.466 \pm 0.379986,22.799 \pm$ 0.802759, $26.266 \pm 0.641006,32.799 \pm 0.900512,36.732 \pm 0.641344 \mathrm{mg}$ of protein/100mg dry wt in respective organs.

In $\mathrm{LC}_{0}(38.5 \mathrm{ppm})$ protein content was present in ascending order of hepatopancreas $<$ gill $<$ mantle $<$ foot $<$ 
Table 1. Imidacloprid induced alterations in the total Protein content of $K$. opima after acute exposure.

\begin{tabular}{|c|c|c|c|}
\hline Tissue & Control & $\mathrm{LC}_{0}$ Group & LC $_{50}$ Group \\
\hline Gill & $16.466 \pm 0.379986$ & $\begin{array}{c}15.266 \pm 0.795843 \\
(-7.28)^{*}\end{array}$ & $\begin{array}{c}17.266 \pm 0.86278 \\
(5.66)^{* *}\end{array}$ \\
\hline Mantle & $22.799 \pm 0.802759$ & $\begin{array}{c}18.266 \pm 0.924902 \\
(-19.00)^{*}\end{array}$ & $\begin{array}{c}21.532 \pm 0.960318 \\
(-7.89)^{*}\end{array}$ \\
\hline H.P. & $13.732 \pm 0.434524$ & $\begin{array}{c}12.332 \pm 0.849771 \\
(-10.19)^{*}\end{array}$ & $\begin{array}{c}13.399 \pm 0.795781 \\
(-2.42)^{*}\end{array}$ \\
\hline Foot & $26.266 \pm 0.641006$ & $\begin{array}{c}23.532 \pm 0.691319 \\
(-12.18)^{*}\end{array}$ & $\begin{array}{c}17.999 \pm 0.505481 \\
(-31.47)^{*}\end{array}$ \\
\hline Male Gonad & $36.732 \pm 0.641344$ & $\begin{array}{c}32.666 \pm 0.623654 \\
(-11.06)^{*}\end{array}$ & $\begin{array}{c}29.932 \pm 0.98863 \\
(-18.51)^{*}\end{array}$ \\
\hline Female Gonad & $32.799 \pm 0.900512$ & $\begin{array}{c}30.266 \pm 1.016301 \\
(-6.19)^{*}\end{array}$ & $\begin{array}{c}26.866 \pm 0.900494 \\
(-17.96)^{*}\end{array}$ \\
\hline
\end{tabular}

female gonad < male gonad with $12.332 \pm 0.849771,15.266 \pm 0.795843,18.266 \pm 0.924902,23.532 \pm 0.691319$, $30.266 \pm 1.016301,32.666 \pm 0.623654 \mathrm{mg}$ of protein/100mg dry wt. In $\mathrm{LC}_{0}$ group as compared to control there was $19.88 \%, 11.06 \%, 10.40 \%, 10.19 \%, 7.72 \%$ and $7.28 \%$ decrease in mantle, male gonad, foot, hepatopancreas, female gonad and gill respectively.

In $\mathrm{LC}_{50}(86.6 \mathrm{ppm})$ group, protein content was present in ascending order of, hepatopancreas $<$ gill $<$ foot $<$ mantle $<$ female gonad < male gonad containing $13.399 \pm 0.795781,17.266 \pm 0.86278,17.999 \pm 0.505481$, $21.532 \pm 0.960318,26.866 \pm 0.900494,29.932 \pm 0.98863 \mathrm{mg}$ of protein/100mg dry wt respectively. As compared to control group, there was increase in protein content of gills as $4.85 \%$ and $31.98 \%, 19.78 \%, 18.08 \%$, $4.96 \%$ and $2.42 \%$ decrease in foot, male gonad, female gonad, mantle and hepatopancreas respectively.

\section{Discussion}

After acute exposure of imidacloprid, clams from $\mathrm{LC}_{0}$ group showed significant decrease in protein content in all target organs. In $\mathrm{LC}_{50}$ group protein content showed significant decrease in mantle, hepatopancreas, foot, male gonad and female gonad and increase in protein content was observed in gill. It may attributed to their primness, impairment of protein synthesis and increase in the rate of their degradation into amino acids, which may be fed to TCA cycle through amino transferase probably due to the high energy demand to cope with the stress condition. It supports the idea of consumption of amino acid for metabolic processes as energy source [7].

Decrease in protein level might be due to increased proteolytic activity or anaerobic conditions produced by pesticide [8]. Increase in protease activity also supported depletion of protein content [9]. Increased protease activity was also observed in molluscs after pesticide treatment [10] [11]. Depletion of protein content in animal tissue after exposure to various pollutants was reported by some workers. Lomte and Alam (1982) reported depletion of protein content in various body tissues of snail, Bellamia bengalensis after malathion treatment [12]. Waykar and V. S. Lomte (2001) also observed the total protein content of all tissue of fresh water bivalve, Parreysia cylindrical after cypermethrin exposure [13]. Swami et al. (1983) recorded significant decline in protein content in freshwater mussel Lamellidens marginalis exposed to fluroid and metacid [14]. Ramana Rao and Ramamurthi (1978) observed alteration in protein content in tissue of Pila globosa after sumithion exposure [15]. Chaudhari and Kulkarni (1998) reported the significant decrease in the protein content due to the active use of proteins for overcoming to the molluscicidal stress [16].

The protein content was decreased in various tissues in $\mathrm{LC}_{0}$ group as compared to control. In $\mathrm{LC}_{50}$ group protein content decreased in mantle, hepatopancreas, foot, male gonad and female gonad as compared to control. This decrease was more in foot, male gonad and female gonad in $\mathrm{LC}_{50}$ group as compared to $\mathrm{LC}_{0}$ group. Gill, mantle, hepatopancreas showed increase in protein content in $\mathrm{LC}_{50}$ group as compared to $\mathrm{LC}_{0}$ group. Decrease in protein content was more in foot, male gonad and female gonad in $\mathrm{LC}_{50}$ group due to higher concentrations of imidacloprid. Decrease in protein level might be due to increased proteolytic activity or anaerobic condition produced by pesticidal stress. Increased protein level might be due to enhanced protein synthesis induced by pesticide at transitional level. 


\section{References}

[1] Kidd, H. and James, D., Eds. (1994) Agrochemicals Handbook. 3rd Edition, Royal Society of Chemistry, Cambridge.

[2] Meister, R.T., Ed. (1995) Farm Chemicals Handbook, 95. Meister Publishing Company, Willoughby.

[3] Waykar, B. and Lomte, V.S. (2001) Total Protein Alteration Indifferent Tissues of Fresh Water Bivalve, Parisians cylindrica after Cypermethrin Exposure. Ecology Environment and Conservation, 7, 465-469.

[4] Mane, U.H. and Gokhale, A.A. (2002) Fluoride Toxicity to the Estuarine Bivalve Molluscs. Journal of Marine Biological Association of India, 40, 16-29.

[5] Prabhupatkar, M.M. (2004) Cypermethrin Induced Toxicity to the Estuarine Clam, Meretrix meretrix (Linnaeus). M.Sc. Thesis, Mumbai University, Mumbai.

[6] Lowry, C.H., Rosenbrough, N.J., Farr, A.L. and Randall, R.J. (1951) Protein Measurement with Folin Phenol Reagent. Journal of Biological Chemistry, 193, 265-275.

[7] Jha, B.S. (1988) Effect of Lead Nitrate on Certain Organs of Air Breathing Teleost Channa punctatus. Ph.D. Thesis, L. N. Mithila University, Darbhanga.

[8] Sivaprasad Rao, K. and Ramana Rao, K.V. (1980) Effect of Insecticide on Freshwater Snail. Telugu Vydhanika Patrika, 9, 27-32.

[9] Srinivas, P. and Purushottam Rao (1987) Biochemical Effects of Phosphomidon on Silk Gland and Other Tissues of Bombyx mori (L.). Proceeding of National Symposium on Environmental Pollution and Pesticide Toxicology and $8^{\text {th }}$ Annual Session of Academy of Environment Biology, University of Jammu, 10-12 December 1997, 173-176.

[10] Jadhav, S.M. (1993) Impact of Pollutants on Some Physiological Aspect of the Fresh Water Bivalve. Corbicula straitella. Ph.D. Thesis, Marathwada University, Aurangabad.

[11] Waykar, B.B. (1998) Effect of Pesticides on Some Physiological Activities of Fresh Water Bivalve, Parreysia cylindrica. Ph.D. Thesis, Dr. Babasaheb Ambedkar Marathwada University, Aurangabad.

[12] Lomte, V.S. and Alam, S. (1982) Changes in the Biochemical Components of the Prosobranch bellamia (V). bengalensis on Exposure to Malathionn. Proceeding of Symposium on Physiology Respiration Anima Pollutants, Marathwada University, Aurangabad, 69-72.

[13] Waykar, B. and Lomte, V.S. (2001) Total Protein Alternation in Different Tissue of Freshwater Bivalve, Parreysia cylindrica after Cypermethrin Exposure. Ecology Environment and Conservation, 7, 465-469.

[14] Swami, K.S., Rao, J.K.S., Reddy, S.K., Srinivasamoorthy, K., Moorthy, L.C., Chetty, C.S. and Indira, S.K. (1983) The Possible Metabolic Diversions Adapted by the Freshwater Mussel to Control the Toxic Metabolic Effect of Selected Pesticides. Indian Journal of Comparative and Animal Physiology, 1, 95-103.

[15] Ramana Rao, M.V. and Ramamurthi, R. (1978) Studies on the Metabolism of the Apple Snail, Pilaglobosa (Swainson) in Relation to Pesticide Impact. Indian Journal of Heritage, 11, 10.

[16] Chaudhari, R.D. and Kulkarni, A.B. (1998) Alterations in Protein Content in the Reproductive Organs of the Snail, Cerastus monssonianus Due to Monocrotophos Intoxication. Pollution Research, 17, 325-329. 